\title{
Sceptical employees as CSR ambassadors in times of financial
}

\author{
uncertainty
}

Dr Anastasios Theofilou and Prof. Tom Watson

This article is (c) Emerald Group Publishing and permission has been granted for this version to appear here (please insert the web address here). Emerald does not grant permission for this article to be further copied/distributed or hosted elsewhere without the express permission from Emerald Group Publishing Limited. 
Purpose - This chapter offers new insights into the understanding of internal (employee) perceptions of organizational corporate social responsibility (CSR) policies and strategies.

Methodology/approach - This study explores the significance of employees' involvement and scepticism upon CSR initiatives and focuses on the effects it may have upon word of mouth (WOM) and the development of employee_organisation relationships. Desk research introduces the research questions. Data for the research questions were gathered through a self-completion questionnaire distributed in a hardcopy form to the sample.

Findings - An individual's level of scepticism and involvement appears to affect the development of a positive effect on employees' WOM. Involvement with the domain of the investment may be a central factoraffecting relationship building within the organization, and upon generation

of positive WOM.

Practical implications - The chapter offers a conceptual framework to public relations (PR) and corporate communications practitioners, which may enrich their views and understanding of the use and value of CSR for communication strategies and practices.

Social implications - For-profit organisations are major institutions in today's society. CSR is proffered as presenting advantages for (at macro level) society and (micro level) the organization and its employees.

Originality/value of chapter - Concepts, such as involvement and scepticism, which have not been rigorously examined in PR and corporate communication literature, are addressed. By examining employee perceptions, managers and academic researchers gain insights into the acceptance, appreciation and effectiveness of CSR policies and activities upon the employee stakeholder group. This will affect current and future CSR communication strategies. The knowledge acquired from this chapter may be transferable outside the for-profit sector.

Keywords: Corporate social responsibility; CSR; employee communication; internal CSR; involvement; relationship building; scepticism; word of mouth

This article is (C) Emerald Group Publishing and permission has been granted for this version to appear here (please insert the web address here). Emerald does not grant permission for this article to be further copied/distributed or hosted elsewhere without the express permission from Emerald Group Publishing Limited. 


\section{Introduction}

As the importance of corporate social responsibility (CSR) continues to rise (Zerfass, Verhoeven, Tench, Moreno, \& Verčič, 2011; Zerfass, Tench, Verhoeven, Verčič, \& Moreno, 2010), several studies have been conducted investigating the effects that CSR may have on organisations (Sen \& Bhattacharya, 2001; Turker, 2009; Verboven, 2011). The mainstream of the CSR research has focused so far on examining the consumers' attitudes and behavioural intentions towards an organisation's CSR investment (Creyer \& Ross, 1997; Maignan, 2001). Research outcomes indicate that stakeholders expect organisations to behave in an ethical manner (Schlegelmilch, 1997) and show concern for social issues (Shaw \& Shiu, 2003). Even though organisations have expanded and enriched their CSR agenda over the years (Kotler \& Lee, 2005) and do not solely focus on environmental concerns anymore, as this may have been the case in the late 1980s and early 1990s (L'Etang, 1994), it is debatable whether an organisation will eventually be rewarded (Laczniak \& Murphy, 1993) or not (Carrigan \& Attala, 2001) for undertaking CSR initiatives.

This study explores the effect of CSR on employees as this is an understudied stakeholder group (Aguilera, Rupp, Williams \& Ganapathi, 2007; Dhanesh, 2012a). More specifically, as CSR means "different things to different people" (Jones, Bowd \& Tench, 2009, p. 303), this study will explore the significance of scepticism as a personality trait upon CSR initiatives and will focus on the effects it may have upon word-of-mouth (WOM) and the development of employee-organisation relationships. Moreover this study will also examine the outcome of the individual's involvement with the domain of the CSR investment upon the cultivation of word-ofmouth (WOM) and the employee-organisation relationship.

\section{Literature review of CSR in the public relations (PR) sphere}

This article is (C) Emerald Group Publishing and permission has been granted for this version to appear here (please insert the web address here). Emerald does not grant permission for this article to be further copied/distributed or hosted elsewhere without the express permission from Emerald Group Publishing Limited. 
This review considers the concepts of corporate social responsibility, its link with public relations and its communication to stakeholders in order to shape the research study.

\section{Corporate social responsibility}

The nature of corporate social responsibility is interdisciplinary and has been examined from different angles (Dhanesh, 2012b). CSR is the response to the call for more ethical business practices in a changing global environment and there is no single way to understand or approach it. Taking into consideration Carroll's (1991) research, which has been used as a benchmark when exploring the field, CSR appears to encompass four levels of responsibility i.e. economic, legal, ethical and philanthropic responsibility. Additionally, Jones et al. (2009) offer a new perspective to Carroll's research capturing better the dynamic and complexity of the phenomenon. Jones et al. (2009) placed the aspects that encompass CSR on continua arguing that CSR is the "good" side of an ethical behaviour in contrast to corporate social irresponsibility (CSI) when discussing the CSI-CSR framework. They argue that stakeholders mistakenly align CSR with both responsible and irresponsible behaviours.

CSR should be focused on good citizenship (Kampf, 2007; Maignan \& Ferrel, 2001) and understanding both community and stakeholder needs (Kitchen, 1997), in order to develop long-lasting beneficial organisation-stakeholder relationships. The question of who is entitled to the CSR leadership (within an organisation) remains unanswered (Dhanesh, 2012b) even though CSR has a clear connection to public relations (PR) theory and practice (L'Etang, 1994).

\section{Public relations and corporate social responsibility}

The concepts of public relations and social responsibility are closely related. In an exploratory study, Kim and Reber (2008) reported that in the organisation PR

This article is (C) Emerald Group Publishing and permission has been granted for this version to appear here (please insert the web address here). Emerald does not grant permission for this article to be further copied/distributed or hosted elsewhere without the express permission from Emerald Group Publishing Limited. 
may have: (a) a significant management role, advocating the importance of CSR, (b) a philanthropic role emphasizing on the charitable giving and relationship-building, (c) a value driven role, promoting the ethical aspects of the organisation, (d) a communication role, where the organisation is only communicating the CSR messages, and (e) no role, which is the case when PR has little involvement with CSR. From their study it may be deduced that, by increasing the influence the organisation has on the stakeholders, the performance of the organisation improves (Kim \& Reber, 2008).

PR establishes relationships between the organization and its stakeholders internally and externally (Ledingham \& Brunning, 2000). The discipline enhances the public dialogue which will lead to a better society and strong community relations (Heath \& Coombs, 2006) by identifying and increasing the involvement of the stakeholders (Hallahan, 2000a, 2000b).

The role of modern organisations is beyond simply generating sales and expanding their share of the market (Kitchen, 1997), while Tench (2009), taking it a step further, discusses how organisations have re-evaluated or should re-evaluate their role in society by adopting a socially responsible framework.

The PR literature has predominately focused on the communication of CSR activities towards stakeholders (Branco \& Rodrigues, 2006; O'Connor \& Meister, 2007; Ellerup-Nielsen \& Thomsen, 2007; Capriotti \& Moreno, 2007; Pomering \& Johnson, 2009; Sones, Grantham \& Vieira, 2009; Rolland \& O’Keefe Bazzoni, 2009; Ellerup-Nielsen \& Thomsen, 2009; Kim, Nam \& Kang, 2010) and mainly consumers (Schmeltz, 2012; Kim \& Lee, 2012). To the contrary the effects of CSR initiatives upon employees remain understudied (Spangler \& Pompper, 2011; Dhanesh, 2012a).

\section{Employees and CSR in public relations literature}

As the organisation attempts to approach various stakeholders with different beliefs and perceptions of CSR understanding the stakeholder group is essential. Employees are a stakeholder group that should be valued (Tench, Bowd and Jones, This article is (c) Emerald Group Publishing and permission has been granted for this version to appear here (please insert the web address here). Emerald does not grant permission for this article to be further copied/distributed or hosted elsewhere without the express permission from Emerald Group Publishing Limited. 
2007). Similar to the PR practitioners who interact with external stakeholders and external environment of the organisation purposefully (Burk, 1994) employees interact with external stakeholders on a voluntary basis as well (Grunig, Grunig \& Dozier, 2002). This means that either officially (i.e. while engaging with activities when on duty) or unofficially (i.e. when off duty or engaging in a spontaneous conversations) the employees may act, intentionally or unintentionally, to a certain extent as boundary spanners (Levina \& Vaast, 2005).

Cameron and McCollum (1993) noted the importance of both good interpersonal relations and employee involvement in the communication process in the better facilitation of two-way communication, while according to Theaker (2008), good employee relations are necessary when aiming for effective external relations.

Developing relationships with the employees is a complicated subject which depends on the structure and culture of the organisation (Puchan, Pieczka \& L'Etang, 1997; Yeomans, 2009) as well as two-way communication within the organisation (Grunig, Grunig \& Dozier, 2002).

\section{Conceptualising the study}

Spangler and Pompper (2011) discussed the importance of focusing on employees and argued that the success of CSR depends on the trust these policies and activities earn from these publics. Their research showed the importance of focusing CSR investments in community relations; a finding which partly has resonance with Uusi-Rauva and Nurkka (2010) who questioned the effectiveness that environmental CSR may have on employee relations.

CSR may lead to competitive advantage when the investment involves engagement with ethical and philanthropic activities (Podnar \& Golob, 2007) or even become a partial antidote to recession (Langford, 2009). Involvement with such social activities reveals the organisation's willingness to cultivate a socially

This article is (C) Emerald Group Publishing and permission has been granted for this version to appear here (please insert the web address here). Emerald does not grant permission for this article to be further copied/distributed or hosted elsewhere without the express permission from Emerald Group Publishing Limited. 
responsible profile which may lead to effective organisation-public relationships (Hon \& Grunig, 1999).

Investing in social activities may be considered a PR strategy affecting organisation-public relationships when it includes the relationship-building components of trust, control mutuality, satisfaction and commitment (Hon \& Grunig, 1999; Huang, 2001).

Trust is one of the key relational indicators. It concerns the belief of one party in the trustworthiness, the integrity and the reliability of the other (Morgan \& Hunt, 1994).

Control Mutuality is about the power that each party (organisation stakeholder group) has in the relationship (Grunig \& Huang, 2000). This power signifies that control that each party has on the other (Hon \& Grunig, 1999).

Satisfaction reveals the degree of favourability between the parties. The positive actions of one party reveal its willingness to maintain and improve the relationship (Huang, 2001).

Commitment is "the extent to which both parties believe and feel that the relationship is worth spending energy on to maintain and to promote" (Grunig, 2002, p.2). The view a stakeholder has towards CSR affects the commitment (Dhanesh, 2012a), while in order to develop a successful CSR strategy, employee commitment is considered to be a crucial factor (Morsing, Schultz \& Nielsen, 2008).

The field in which CSR investment is made is surely a very important factor to the organisation-employee relationship building (Uusi-Rauva \& Nurkka, 2010; Podnar \& Golob, 2007); however, Morsing et al (2008) highlight the importance of ensuring the employees' involvement with the CSR strategy before anything else. Therefore employees' involvement with the domain of investment should be examined.

Involvement has been considered a valuable predictor of activism (Grunig \& Hunt, 1984), while it is also regarded a predictor of the individuals "willingness to process a message as well as the likelihood that existing message content will be used to assess each new message" (Heath \& Douglas, 1991, p. 179). Hallahan

This article is (C) Emerald Group Publishing and permission has been granted for this version to appear here (please insert the web address here). Emerald does not grant permission for this article to be further copied/distributed or hosted elsewhere without the express permission from Emerald Group Publishing Limited. 
(2000a) discusses how the concepts of involvement and knowledge complete each other and considers high involvement one of the most important ingredients of active publics. The current research explores the effect that an individual's "personal relevance" with the domain of the investment may have on the outputs and outcomes of the organisation's CSR.

Even though CSR illustrates the "ethic of care" which may be considered proof of how an organisation appreciates the stakeholders (Coombs \& Holladay, 2007), in many cases the motives of organisations undertaking CSR initiatives are questioned. The reasons which lead an organisation to embark on CSR activities depend on the its objectives and how CSR is perceived by its decision makers. According to Tench et al (2007), from a media perspective, organisations tend to engage with CSR through at least one of five orientations. Organisations may: (a) follow their competitors' strategy (Conformist), (b) do it out of self-interest (Cynic), (c) invest in CSR recognizing the benefits but understanding at the same time the limitations (Realist), (d) focus on the positive effects of CSR (Optimist), or (e) appreciate CSR as a long term strategy with mainly positive attributes (Strategic Idealist).

Regardless of the orientation, the media's tendency to report mainly the irresponsible aspects of an organisation (Tench et al, 2007) and the stakeholder misconception of CSR due to the lack until recently of an integrated CSI-CSR framework (Jones et al, 2009) has led the stakeholders to take a more sceptical approach towards the phenomenon.

Scepticism involves questioning motives, facts, existing knowledge and generally any kind of doctrinaire belief. It has been the focus of several studies but not in the field of PR. Mohr, Eroglu and Ellen (1998) examined the influence of consumers' scepticism on environmental claims and effects of products and packaging, while Obermiller and Spangenberg (1998) explored consumer scepticism and attitudes towards advertising. As the latter researchers questioned the suitability of their scale outside the advertising context this study examines

This article is (C) Emerald Group Publishing and permission has been granted for this version to appear here (please insert the web address here). Emerald does not grant permission for this article to be further copied/distributed or hosted elsewhere without the express permission from Emerald Group Publishing Limited. 
scepticism as a personality trait within the PR discipline by relying on the outcomes of Hurtt (2010). Hurtt's study explored scepticism as a personality trait and proposed six characteristics of professional scepticism: questioning mind, suspension of judgement, search for knowledge, interpersonal understanding, autonomy and selfesteem. Scepticism is concerned with questioning and having a sense of doubting (questioning mind) (ibid). A questioning mind reaches a verdict and conclusions once all persuasive evidence is gathered (aka suspension of judgement). Besides having a doubting nature a sceptical individual may also have a certain level of curiosity which will lead to the search for knowledge (ibid). Interpersonal understanding focuses on identifying the motives, the perceptions and generally the behaviour and attitude of other people. Failing to do that, the individual will most probably be biased when reaching conclusions (ibid). The "autonomy" dimension of scepticism regards the self-determining aspect of the individual not to accept passively claims and information but to slowly and objectively gather and evaluate this information ignoring the attempts of other parties to persuade him/her (ibid). Finally Hurtt (2010) recognizes self-esteem as a characteristic of scepticism and discusses it as the individual's ability to feel confident and self-assured. Self-esteem is an important characteristic especially because it is one of the factors influencing the individual's ability to raise arguments openly.

Acknowledging that external stakeholders do not appreciate the "loud" communication of CSR activities (Morsing et al, 2008) organisations should be examining more subtle methods of communicating their CSR messages.

Employees are an extension of the organisation and therefore when associating with other stakeholders may share with them their opinion concerning the organisation. Through this association the employees fulfil an intended (or not) boundary spanning role communicating informally with their social and cultural environment. Goyette, Ricard, Bergeron and Marticotte (2010) and Lin and Liao (2008) have analyzed the literature focusing on Word of Mouth. They found that word of mouth is an informal form of communication from one individual to

This article is (C) Emerald Group Publishing and permission has been granted for this version to appear here (please insert the web address here). Emerald does not grant permission for this article to be further copied/distributed or hosted elsewhere without the express permission from Emerald Group Publishing Limited. 
another. The content is the expression of a personal point of view without obvious commercial purposes. The reasons enhancing this behaviour may vary. The individual who feels the need to communicate has had some sort of interesting experience with an organisation. The consequences of this interplay trigger the need to communicate the experience with his/her environment.

\section{Research Questions}

This study will attempt to examine the impact that the individual's involvement with the domain may have on the dimensions of relationship management and word of mouth. Therefore the first research question addressed is:

RQ1: Is involvement with the domain of the CSR investment a significant predictor for: a) the dimensions of relationship management and b) positive word of mouth?

As the individual's scepticism defines his/her personality the research will explore the effect that the dimensions of scepticism may have on the dimensions of relationship management, CSR and word of mouth. The research question proposed is:

RQ2: Which dimensions of scepticism may be considered significant predictors for: a) the dimensions of relationship management and b) positive word of mouth?

Given that the interplay between CSR and employees has been understudied, this chapter will examine the impact that the dimensions of CSR may have on the dimensions of relationship management within organisations. The research question is:

RQ3: Are the dimensions of CSR significant predictors of the dimensions of relationship management?

Finally, following the relational approach of $\mathrm{PR}$, this research will attempt to investigate the impact of the dimensions of relationship management on word-ofmouth. The research question framed is:

This article is (C) Emerald Group Publishing and permission has been granted for this version to appear here (please insert the web address here). Emerald does not grant permission for this article to be further copied/distributed or hosted elsewhere without the express permission from Emerald Group Publishing Limited. 
RQ4: Which dimensions of relationship management are significant predictors of word of mouth in relation to CSR?

\section{Methodology}

In order to assess the employee's role in CSR initiatives, we had two goals in our study design: (a) surveying a large sample of employees and (b) using an organisation that was well-known in its industry and within its country. Therefore, one of the 30 largest organisations in Greece (To Vima, 2012) was recruited for participation in this study. The organization was one of the first in Greece to adopt CSR best practices and is one of the domestic leaders in CSR investments focusing on employees. The organisation has a very comprehensive CSR strategy focusing on the pillars of environment, society, marketplace and human resources, international presence and over 7,000 employees worldwide. The research examined the case of the organisation's social policies and specifically the case of CSR activities organized for the relief of children in need. For the communication of the CSR messages the organisation uses a mixture of strategies such as face-to-face communication, intranet, publicizing annual reviews, holding meetings, emails, websites (White, Vanc \& Stafford, 2010; Welch, 2012) and social media (Friedl \& Vercic, 2011). It was thus not reliant on external media as a primary method of communication with employees.

\section{Research Design}

Data for the research questions were gathered through a self-completion questionnaire distributed in a hardcopy form to the employees located in the organisation's central office in Athens. A convenience sample (Bryman, 2008) of 612 complete questionnaires was gathered. The questionnaires were distributed and collected by a research assistant who is not an employee of the organisation. Moreover it was clearly stated, on the questionnaire and by the individual

This article is (C) Emerald Group Publishing and permission has been granted for this version to appear here (please insert the web address here). Emerald does not grant permission for this article to be further copied/distributed or hosted elsewhere without the express permission from Emerald Group Publishing Limited. 
distributing the questionnaires, that the responses are strictly confidential and the purpose was for scientific research. Therefore we do not expect social desirability bias and perception bias to be threats to the validity of this study. Some $61.77 \%$ of the respondents were males $(n=378)$, while the $38.23 \%$ were females $(n=234)$.

The questionnaire used a seven-point Likert scale in order to examine the relationships between: positive word of mouth, involvement (i.e. involvement with children donations and involvement with philanthropies), scepticism (i.e. selfdetermination, the individual's questioning mind, search for knowledge, selfconfidence, suspension of judgement, interpersonal understanding), views on CSR (i.e. discretionary CSR, ethical-legal CSR, economic CSR) and relationship management (i.e. control mutuality, relationship commitment, relationship satisfaction, trust). The questions included in the questionnaire are presented in Table 1.

Table 1

The data are processed with SPSS 19 and analysed with multiple regressions. The first multiple regression examined the effect of control mutuality, relationship commitment, relationship satisfaction, trust, self-determination, the individual's questioning mind, search for knowledge, self-confidence, suspension of judgement, interpersonal understanding, involvement with children donations and involvement with philanthropies upon word of mouth answering to research questions RQ1b, RQ2b and RQ4. The second multiple regression examined the effect of the individual's self-determination, questioning mind, search for knowledge, selfconfidence, suspension of judgement, interpersonal understanding, discretionary CSR, ethical-legal CSR, economic CSR, involvement with children donations and This article is (C) Emerald Group Publishing and permission has been granted for this version to appear here (please insert the web address here). Emerald does not grant permission for this article to be further copied/distributed or hosted elsewhere without the express permission from Emerald Group Publishing Limited. 
involvement with philanthropies upon control mutuality. The third multiple regression examined the effect of the individual's self-determination, questioning mind, search for knowledge, self-confidence, suspension of judgement, interpersonal understanding, discretionary CSR, ethical-legal CSR, economic CSR, involvement with children donations and involvement with philanthropies upon relationship commitment. The fourth multiple regression examined the effect of the individual's self-determination, questioning mind, search for knowledge, selfconfidence, suspension of judgement, interpersonal understanding, discretionary CSR, ethical-legal CSR, economic CSR, involvement with children donations and involvement with philanthropies upon relationship satisfaction. Finally the fifth multiple regression examined the effect of the individual's self-determination, questioning mind, search for knowledge, self-confidence, suspension of judgement, interpersonal understanding, discretionary CSR, ethical-legal CSR, economic CSR, involvement with children donations and involvement with philanthropies upon trust. The second, third, fourth and fifth multiple regressions answered to research questions RQ1a, RQ2a and RQ3.

\section{Results}

In order to make the results more meaningful a factor analysis is implemented reducing the number of the variables (Aaker, Kumar \& Day, 2007). All items were grouped in sixteen factors. All factors have satisfactory loadings over 0.6 (Hair, Black, Babin, Anderson \& Tatham, 2006). The construct is assessed with Cronbach's alpha coefficient. All measures had an acceptable level of over 0.7 showing good reliability (Nunnally \& Bernstein 1994). Factor loadings and Cronbach's alpha are presented in Appendix 1.

The first regression tested the dependence of positive word of mouth in relation to the dimensions of scepticism, involvement and relationship management. The value of the adjusted $R^{2}$ is 0.780 and for these data $F$ is 376.028 , which is significant at $p<.001$. The coefficients are presented in Table 2 .

This article is (C) Emerald Group Publishing and permission has been granted for this version to appear here (please insert the web address here). Emerald does not grant permission for this article to be further copied/distributed or hosted elsewhere without the express permission from Emerald Group Publishing Limited. 
Table 2

Following, the dependence of the relationship management indicators to the dimensions of scepticism, involvement and views of CSR is tested.

In the case of control mutuality the value of adjusted $R^{2}$ is 0.610 and for these data $F$ is 87.96 , which is significant at $p<.001$ (Table 3 ).

Table 3

In the case of relational commitment the value of the adjusted $R^{2}$ is 0.606 and for these data $F$ is 86.56 , which is significant at $p<.001$ (Table 4).

Table 4

In the case of relational satisfaction the value of the adjusted $R^{2}$ is 0.611 and for these data $F$ is 88.16, which is significant at $p<.001$ (Table 5).

Table 5

This article is (c) Emerald Group Publishing and permission has been granted for this version to appear here (please insert the web address here). Emerald does not grant permission for this article to be further copied/distributed or hosted elsewhere without the express permission from Emerald Group Publishing Limited. 
Finally, in the case of trust the value of the adjusted $R^{2}$ is 0.608 and for these data $F$ is 87.16 , which is significant at $p<.001$ (Table 6).

Table 6

As presented in multiple regression tables no collinearity issues were observed. For all cases both tolerance and VIF indicators were acceptable (Hair, et al, 2006).

\section{Discussion}

Based on the results, involvement and certain dimensions of scepticism appear to be significant predictors of positive word of mouth and the relationship management indicators (Hon \& Grunig, 1999). With regards to the discussion concerning the research questions:

RQ1: Is involvement with the domain of the CSR investment a significant predictor for: a) the dimensions of relationship management and b) positive word of mouth?

As observed employees who are already involved with the domain of the CSR investment feel that the organization is building a solid relationship with them. When CSR is linked with issues of employees' personal relevance then the employees perceive this as a benefit provided to them by the organisation (Bhattacharya, Korschun \& Sen, 2009). Certain employees may even seek to develop their relationship with the organisation in order to obtain the benefits provided (Bhattacharya et al, 2009). It is recommended that organisations acknowledge the areas of employee involvement outside the workplace and aim their activities and policies towards these areas. It is observed that organisations invest in CSR and then

This article is (C) Emerald Group Publishing and permission has been granted for this version to appear here (please insert the web address here). Emerald does not grant permission for this article to be further copied/distributed or hosted elsewhere without the express permission from Emerald Group Publishing Limited. 
direct the employees to identify the relevance of the CSR investment to themselves (Uusi-Rauva \& Nurkka, 2010), rather than the other way round.

It also appears that employees appreciate philanthropically-focused CSR. This may be considered as something beyond corporate community investments, even though the latter is both effective and necessary (Langford, 2009).

The managerial implication of the discussion for this research question is twofold. Organisations may consider investing their CSR budgets by helping directly members of the society and link it to employee involvement. Involvement seems to be a significant predictor for both relationship indicators and of positive word of mouth. Once employees understand the CSR messages, it may be expected afterwards that they show more willing to process future CSR messages based on existing experience (Heath \& Douglas, 1991).

RQ2: Which dimensions of scepticism may be considered significant predictors for: a) the dimensions of relationship management and b) positive word of mouth?

Scepticism helps define the personality of the individual and reveals a story of his/her background. From the findings it is suggested that certain dimensions of scepticism affect positively the dimensions of relationship management. A questioning mind, self-confidence, and interpersonal understanding may be significant predictors of the individual's commitment when it comes to CSR investments. The individual's questioning mind and the variable of quest for knowledge are significant predictors of control mutuality. Finally self-determination, adequacy of information and time to absorb the reasoning behind a CSR investment are significant predictors of satisfaction and trust. Even though employees understand the organisation's self-promotion, they were found to sense a relationship being built. Sceptical employees identify that the company is attempting at least to give something back to a higher cause with significant societal impact without examining if the organisation cares or "pretends" to care about good citizenship.

This article is (C) Emerald Group Publishing and permission has been granted for this version to appear here (please insert the web address here). Emerald does not grant permission for this article to be further copied/distributed or hosted elsewhere without the express permission from Emerald Group Publishing Limited. 
Employees with a questioning nature who do not rush into decisions (suspension of judgment) may share this way of thinking with their close environment through positive word of mouth.

This discussion may offer insight with regards to the development of the communication strategy and the effects of the CSR strategy. Understanding the levels of employees' scepticism should be a by-default requirement before developing a CSR strategy.

RQ3: Are the dimensions of CSR significant predictors of the dimensions of relationship management?

As identified above, CSR practice and communication interacts with PR practices and it may be worth examining the effect it has on the relationship management indicators. The dimensions of CSR seem to be significant predictors of relationship quality. However, an analysis of the external environment in which the organisation is operating should be undertaken (Wang \& Chaudhri, 2009). Depending on the country's political, environmental, legal, economical and societal structure publics may be more (un)sensitive towards CSR activities. Even though it is not one of the findings of this study, it has been observed that employees may not always be impressed and may express their scepticism when organisations just fulfil their discretionary and economic CSR “obligations" (Dhanesh, 2012a).

The main outcome of this discussion is the need for deeper and more ethical understanding of the dynamic nature of CSR (Jones et al, 2009). It is not limited to wording ethical activities differently to avoid the "greenwash" connotation which sometimes accompanies the use of the term CSR. Nor is it concerned with classifying social investments under different themes outside the CSR pillars. It focuses on comprehension of the difference between social responsibility and social irresponsibility and the effect that both concepts may have on relationship building.

RQ4: Which dimensions of relationship management are significant predictors of word of mouth in relation to CSR?

This article is (C) Emerald Group Publishing and permission has been granted for this version to appear here (please insert the web address here). Emerald does not grant permission for this article to be further copied/distributed or hosted elsewhere without the express permission from Emerald Group Publishing Limited. 
Employees in this study appreciate the decision-making process and the influence they have when it comes to CSR investments in philanthropic activities that target children in need. They seem to trust that the organisation is truthful and will keep its promises. Moreover, social investments of this kind appear to improve the levels of satisfaction and commitment that employees have. Relationship quality indicators are one of the main outcomes of PR (Ledingham \& Bruning, 2000) and appear to be significant predictors of positive word of mouth. Accomplishing a good relationship with the employees before engaging them to CSR activities, as discussed by Morsing et al (2008), is a valuable pre-condition for reduced scepticism and further improvements in management-employee relationships. This outcome even more important when acknowledging that the employees are the "key drivers of CSR" messages, as the media will probably be interested more in the negative aspects than the good deeds of an organisation (Tench et al, 2007). Therefore cultivating positive word of mouth is paramount.

\section{Limitations}

As this research used a convenience sampling approach it is strongly recommended to test the replicability of the findings. Moreover the socio-economic factors and the timing of the research (Summer 2012 in Greece) may also be considered a limitation.

Finally social desirability bias may be considered a limitation as the focus of the study is a sensitive topic concerning children in need in times of huge financial uncertainty.

In terms of future research, cross-sectional and cross-national research are recommended in order to identify the cultural and socio-economic influence on CSR initiatives.

\section{Conclusions}

This article is (C) Emerald Group Publishing and permission has been granted for this version to appear here (please insert the web address here). Emerald does not grant permission for this article to be further copied/distributed or hosted elsewhere without the express permission from Emerald Group Publishing Limited. 
The primary aim of this chapter was to explore the effect that CSR may have on employees' positive word of mouth, when focusing the investment on a societally-linked activity that targets children in need.

Acknowledging the limitations and recommendations for future research the current study reached the following observations and conclusions.

The first is that the relationship indicators affected by the specific investment are significant predictors of positive word of mouth. Without diminishing the importance of the organisation's employee orientation as one of the CSR pillars, corporate social investments may enhance greatly the organisation-employee relationship leading to positive word of mouth. Hence, when an organisation proceeds in investments with high societal impact, employees are positively disposed to share news of this activity with their social and cultural environment.

The second observation concerns the role of the employees' involvement with the domain of investment. Involvement is a significant predictor of the relational quality and positive word of mouth. The reasoning behind this may be linked to social identity theory and the importance of social alliances (Gwinner \& Swanson, 2003). Employees, as members of particular alliances, appreciating that the organisation is supporting the domain in which they are involved, feel a deeper relational connection with the organisation. As a result of further involvement employees share positive information concerning the organisation with the other stakeholder groups with which they either interact or are members of. This observation indicates that when deciding about a CSR investment the domains of employee involvement outside the organisation should be taken into account.

Finally, certain dimensions of scepticism are significant predictors of both relationship building and positive word of mouth. Scepticism in this study is perceived in the form of "watchfulness" (Hurtt, 2010) rather than "suspicion" (Obermiller \& Spangenberg, 1994). Even though highly sceptical individuals may easily spot the organisation's attempt at self-promotion through CSR, it appears that investments affecting community wellbeing and sensitive societal concerns are

This article is (C) Emerald Group Publishing and permission has been granted for this version to appear here (please insert the web address here). Emerald does not grant permission for this article to be further copied/distributed or hosted elsewhere without the express permission from Emerald Group Publishing Limited. 
highly valued. Sceptical employees sense the "greenwash"; however they appreciate that social investment is a way for the organisation to express ethical concerns and become an active caring member of society. Organisations should be able to interpret this as an invitation.

A mutually understood relationship between employees and organization will affect the employees' tendency to communicate positive aspects of the organisation due to their boundary spanning role. Even though focusing on employees is high in the CSR agenda findings suggest that there is room to explore deeper their role by focusing on personality traits. Exploring an individual's scepticism may offer an additional angle to the understanding and investigation of the value of CSR and the importance of the further development of the CSI-CSR framework.

This article is (C) Emerald Group Publishing and permission has been granted for this version to appear here (please insert the web address here). Emerald does not grant permission for this article to be further copied/distributed or hosted elsewhere without the express permission from Emerald Group Publishing Limited. 


\section{References}

Aaker, D., Kumar, V., \& Day, G. (2007). Marketing research (9th ed.). New Jersey: John Wiley \& Sons Inc.

Aguilera, R. V., Rupp, D. E., Williams, C. A., \& Ganapathi, J. (2007). Putting the $S$ back in corporate social responsibility: a multilevel theory of social change in organisations. Academy of Management Review, 32 (3), 946-976.

Bhattacharya, C. B., Korschun D., \& Sen, S. (2009). Strengthening stakeholdercompany relationships through mutually beneficial corporate social responsibility initiatives. Journal of Business Ethics, 85 (1), 257-272.

Branco, C. M, \& Rodrigues, L.L. (2006). Communication of corporate social responsibility by Portuguese banks: A legitimacy theory perspective. Corporate Communications: An International Journal, 11 (3), 232-248.

Bryman, A., (2008). Social research methods (3rd ed.). Oxford: Oxford University Press.

Burk, J. (1994). Training MNC Employees as Cultural Sensitive Boundary Spanners. Public Relations Quarterly, 39 (2), 40-44

Cameron, G. T., \& McCollum, T. (1993). Competing corporate cultures: A multi-method, cultural analysis of the role of internal communication. Journal of Public Relations Research, 5 (4), 217-250.

Capriotti, P., \& Moreno, A. (2007). Communicating corporate responsibility through corporate web sites in Spain. Corporate Communications: An International Journal, 12 (3), 221-237.

Carrigan, M. \& Attalla A. (2001). The myth of the ethical consumer - do ethics matter in purchase behaviour? Journal of Consumer Marketing, 18 (7), 560-578.

Carroll, B. A. (1991). The pyramid of corporate social responsibility: Toward the moral management of organizational Stakeholders. Business Horizons, 34 (4), 3948.

Coombs, W.T., \& Holladay, S. J. (2007). It's not just PR: Public relations in society. Oxford: Blackwell.

This article is (C) Emerald Group Publishing and permission has been granted for this version to appear here (please insert the web address here). Emerald does not grant permission for this article to be further copied/distributed or hosted elsewhere without the express permission from Emerald Group Publishing Limited. 
Creyer, E. H., \& Ross, W. T. (1997). The influence of firm behavior on purchase intention: Do consumers really care about business ethics? Journal of Consumer Marketing, 14 (6), 419-432.

Dhanesh, S. G. (2012a). The view from within: Internal publics and CSR. Journal of Communication Management, 16 (1), 39 - 58.

Dhanesh, S. G. (2012b). Better stay single? Public relations and CSR leadership in India. Public Relations Review, 38 (1), 141 - 143.

Ellerup-Nielsen, A., \& Thomsen, C. (2009). CSR communication in small and medium-sized enterprises: A study of the attitudes and beliefs of middle managers. Corporate Communications: An International Journal, 14 (2), 176 - 189.

Ellerup-Nielsen, A., \& Thomsen, C. (2007). Reporting CSR - what and how to say it? Corporate Communications: An International Journal, 12 (1), 25 - 40.

Fisher, J. R., \& Wakefield, K. (1998). Factors leading to group identification: A field study of winners and losers. Psychology \& Marketing, 15 (1), 24-40.

Friedl, J., \& Vercic, T. A. (2011). Media preferences of digital natives' internal communication: A pilot study, Public Relations Review, 37 (1), 84-86.

Goyette, I., Ricard, L., Bergeron, J., \& Marticotte, F. (2010). E-WOM scale: Word-of-mouth measurement scale for e-Services Context. Canadian Journal of Administrative Sciences, 27 (1), 5-23.

Grunig, J. (2002). Qualitative methods for assessing relationships between organizations and publics. Gainesville, FL: The Institute for Public Relations.

Grunig, J. E., \& Huang, Y. H. (2000). From organizational effectiveness to relationship indicators: Antecedents of relationships, public relations strategies, and relationship outcomes. In Ledingham J. A., \& Bruning S. D. (Eds.), Public relations as relationship management: A relational approach to the study and practice of public relations (pp. 23-53). Mahwah, NJ: Lawrence Erlbaum.

Grunig, J. E., \& Hunt, T. (1984). Managing public relations. Fort Worth, TX: Harcourt Brace.

Grunig, L., Grunig, J., \& Dozier, D. M. (2002). Excellent public relations and

This article is (C) Emerald Group Publishing and permission has been granted for this version to appear here (please insert the web address here). Emerald does not grant permission for this article to be further copied/distributed or hosted elsewhere without the express permission from Emerald Group Publishing Limited. 
effective organizations: a study of communication management in three countries. Mahwah, NJ: Lawrence Erlbaum Associates.

Gwinner, K., \& Swanson, R. S. (2003). A model of fan identification: antecedents and sponsorship outcomes. Journal of Services Marketing, 17 (3), 275 294.

Hallahan, K. (2000a). Inactive publics: The forgotten publics in public relations, Public Relations Review, 26 (4), 499-515.

Hallahan, K. (2000b). Enhancing audience motivation, ability and opportunity to process public relations messages. Public Relations Review, 26 (4), 463-480

Hair, J., Black, W., Babin, B., Anderson, R., \& Tatham, R. (2006). Multivariate data analysis (6th ed.). New Jersey: Prentice-Hall.

Heath, L. R., \& Coombs, W. T. (2006). Today's public relations: An introduction. London: Sage.

Heath, R. L., \& Douglas, W. (1991). Effects of involvement on reactions to sources of messages and to message clusters. Public Relations Research Annual, 3, 179-194.

Hellastat report on 200 largest Greek companies (n.d.). Retrieved January 18, 2012 from http://www.tovima.gr/files/1/2012/01/25/top200.pdf

Hon, L. C., \& Grunig, J. E. (1999). Measuring relationships in public relations. Gainesville, FL: Institute for Public Relations.

Huang, Y. H. (2001). Value of public relations: effects on organization-public relationships mediating conflict resolution. Journal of Public Relations Research, 13(4), 265-301.

Hurtt, R. K. (2010). Development of a scale to measure professional scepticism, A Journal of Practice \& Theory American Accounting Association, 29 (1), 149-171.

Jones, B., Bowd, R., \& Tench, R. (2009). Corporate irresponsibility and corporate social responsibility: Competing realities. Social Responsibility Journal, 5 (3), $300-310$.

This article is (c) Emerald Group Publishing and permission has been granted for this version to appear here (please insert the web address here). Emerald does not grant permission for this article to be further copied/distributed or hosted elsewhere without the express permission from Emerald Group Publishing Limited. 
Kampf, C. (2007). Corporate social responsibility: Wal-Mart, Maersk and the cultural bounds of representation in corporate web sites. Corporate Communications: An International Journal, 12 (1), 41 - 57.

Kim, D., Nam, Y., \& Kang, S. (2010). An analysis of corporate environmental responsibility on the global corporate websites and their dialogic principles. Public Relations Review, 36 (3), 285-288

Kim, S., \& Lee, Y. J. (2012). The complex attribution process of CSR motives. Public Relations Review, 38 (1), 168-170.

Kim, S. Y., \& Reber, B. H. (2008). Public relations' place in corporate social responsibility: Practitioners define their role. Public Relations Review, 34 (4), 337342.

Kitchen, P. J. (1997). Public relations: principles and practice. London: International Thomson Business Press.

Kotler, P., \& Lee, N. (2005). Corporate social responsibility: Doing the most good for your company and your cause. Hoboken, NJ: Wiley.

Laczniak, G. R. \& Murphy, P. E. (1993). Ethical marketing decisions: The higher road, Harlow: Prentice Hall.

Langford, M. (2009). Managing community involvement programmes. In Tench, R., \& Yeomans, L. (Eds.), Exploring public relations (pp. 338 - 364). Harlow: Pearson Education Ltd.

Ledingham, J. A., \& Bruning, S. D. (2000). (Eds.), Public relations as relationship management: A relational approach to the study and practice of public relations, Mahwah, NJ: Lawrence Erlbaum.

Levina, N., \& Vaast, E. (2005). The emergence of boundary spanning competence in practice: implications for implementation and use of information systems. MIS Quarterly, 29 (2), 335-363.

L'Etang, J. (1994). Public relations and corporate social responsibility: Issues arising. Journal of Business Ethics, 13 (2), 111-123.

Lin M. Y. T., \& Liao C. W. (2008). Knowledge dissemination of word-of-mouth

This article is (C) Emerald Group Publishing and permission has been granted for this version to appear here (please insert the web address here). Emerald does not grant permission for this article to be further copied/distributed or hosted elsewhere without the express permission from Emerald Group Publishing Limited. 
research: Citation analysis and social network analysis, Libri, 58 (4), 212-223.

Maignan, I. (2001). Consumers' perceptions of corporate social responsibilities: A cross-cultural comparison. Journal of Business Ethics, 30 (1), 57-72.

Maignan, I., \& Ferrell, O. C. (2001). Corporate citizenship as a marketing instrument: concepts, evidence and research directions. European Journal of Marketing, 35 (3/4), 455-469.

Mohr, L. A., Eroglu, D., \& Ellen, S. P. (1998). The development and testing of a measure of skepticism toward environment claims in the marketers' communications. The Journal of Consumers Affairs, 32 (1), 30-55.

Morgan, R., \& Hunt, S. (1994). The commitment-trust theory of relationship marketing. Journal of Marketing, 58 (3), 20-38.

Morsing, M., Schultz M., \& Nielsen, K. U. (2008). The 'Catch 22' of communicating CSR: Findings from a Danish study. Journal of Marketing Communications, 14 (2), 97-111.

Nunnally, J., \& Bernstein, I.H. (1994). Psychometric theory (3rd ed.). New York: McGraw-Hill.

Obermiller, C., \& Spangenberg, E. R. (1998). Development of a scale to measure consumer skepticism toward advertising. Journal of Consumer Psychology, 7 (2), 159-186.

O'Connor A., \& Meister, M. (2007). Corporate social responsibility attribute rankings. Public Relations Review, 34 (1), 49-50.

Podnar, K., \& Golob, U. (2007). CSR expectations: the focus of corporate marketing. Corporate Communications: An International Journal, 12 (4), 326-340.

Pomering, A., \& Johnson, W. L. (2009). Advertising corporate social responsibility initiatives to communicate corporate image: Inhibiting scepticism to enhance persuasion. Corporate Communications: An International Journal, 14 (4), $420-439$.

This article is (C) Emerald Group Publishing and permission has been granted for this version to appear here (please insert the web address here). Emerald does not grant permission for this article to be further copied/distributed or hosted elsewhere without the express permission from Emerald Group Publishing Limited. 
Puchan, H., Pieczka, M., \& L’Etang, J. (1997). The internal communication context. In Kitchen, P. (Eds.), Public relations: principles and practice (pp.74 - 88). London: International Thomson Business Press.

Rolland, D., \& O'Keefe Bazzoni, J. (2009). Greening corporate identity: CSR online corporate identity reporting. Corporate Communications: An International Journal, 14 (3), $249-263$.

Schlegelmilch, B. (1997). The Relative Importance of ethical and environmental screening: Implications for the marketing of ethical investment funds, International Journal of Bank Marketing, 15 (2), 48-53.

Schmeltz, L. (2012). Consumer-oriented CSR communication: focusing on ability or morality? Corporate Communications: An International Journal, 17 (1), 29 49.

Sen, S., \& Bhattacharya, C.B. (2001). Does doing good always lead to doing better? Consumer reactions to corporate social responsibility. Journal of Marketing Research, 38 (2), 225-243.

Shaw, D., \& Shiu, E. (2003). Ethics in consumer choice: a multivariate modelling approach. European Journal of Marketing, 37 (10), 1485-1498.

Sones, M., Grantham, S., \& Vieira, T. E. (2009). Communicating CSR via pharmaceutical company web sites: Evaluating message frameworks for external and internal stakeholders. Corporate Communications: An International Journal, 14 (2), $144-157$.

Spangler, S. I., \& Pompper, D. (2011). Corporate social responsibility and the oil industry: Theory and perspective fuel a longitudinal view. Public Relations Review, $37(3), 217-225$.

Tench, R. (2009). Community and society: corporate social responsibility (CSR). In Tench, R., \& Yeomans, L. (Eds.), Exploring public relations (pp. 97-114). Harlow: Pearson Education Ltd.

This article is (C) Emerald Group Publishing and permission has been granted for this version to appear here (please insert the web address here). Emerald does not grant permission for this article to be further copied/distributed or hosted elsewhere without the express permission from Emerald Group Publishing Limited. 
Tench, R., Bowd, R., \& Jones, B. (2007). Perceptions and perspectives: corporate social responsibility and the media. Journal of Communication Management, 11 (4), 348-370.

Theaker, A. (2008). The public relations handbook (3rd ed.). London: Routledge.

Turker, D. (2009). Measuring corporate social responsibility: A scale development study. Journal of Business Ethics, 85 (4). 411-427.

Uusi-Rauva, C., \& Nurkka, J. (2010). Effective internal environment-related communication: An employee perspective. Corporate Communications: An International Journal, 15 (3), 299 - 314. Verboven, H. (2011). Communicating CSR and business identity in the chemical industry through mission slogans. Business Communication Quarterly, 74 (4), 415-431.

Wang, J., \& Chaudhri, V. (2009). Corporate social responsibility engagement and communication by Chinese companies. Public Relations Review, 35 (3), 247-250.

Welch, M. (2012). Appropriateness and acceptability: Employee perspectives of internal communication, Public Relations Review, 38 (2), 246-254.

White, C., Vanc, A., \& Stafford, G. (2010). Internal communication, information satisfaction, and sense of community: The effect of personal influence. Journal of Public Relations Research, 22 (1), 65-84.

Yeomans, L. (2009). Internal communication. In Tench, R., \& Yeomans L. (Eds.), Exploring public relations (pp. 316-336). Harlow: Pearson Education Ltd.

Zerfass, A., Verhoeven, P., Tench, R., Moreno, A., \& Verčič, D. (2011): European Communication Monitor 2011. Empirical Insights into Strategic Communication in Europe. Results of an Empirical Survey in 43 Countries (Chart Version). Brussels: EACD, EUPRERA (available at: www.communicationmonitor.eu)

Zerfass, A., Tench, R., Verhoeven, P., Verčič, D, \& Moreno, A (2010): European Communication Monitor 2010. Status Quo and Challenges for Communication Management in Europe - Results of an Empirical Survey in 46 Countries. Brussels: EACD, EUPRERA

This article is (C) Emerald Group Publishing and permission has been granted for this version to appear here (please insert the web address here). Emerald does not grant permission for this article to be further copied/distributed or hosted elsewhere without the express permission from Emerald Group Publishing Limited. 
Table 1: Measures and items of research

\begin{tabular}{|c|c|c|}
\hline Author & Concept & Variables and items \\
\hline Dhanesh (2012) & Views on CSR & $\begin{array}{l}\text { Discretionary CSR } \\
\text { 1.This organisation gives adequate contribution to charities } \\
\text { 2. This organisation encourages partnership with local businesses and } \\
\text { schools } \\
\text { Ethical-legal CSR } \\
\text { 1.Flexible company policies enable employees to better co-ordinate } \\
\text { work and personal life } \\
\text { 2. Fairness towards co-workers and business partners is an integral } \\
\text { part of our employee evaluation process } \\
\text { 3. A confidential procedure is in place for employees to report any } \\
\text { misconduct at work } \\
\text { 4. Our salespersons and employees are required to provide full and } \\
\text { accurate information to all customers } \\
\text { 5. This company seeks to comply with all laws regulating hiring and } \\
\text { employee benefits } \\
\text { 6. This organisation has programmes that encourage the diversity of } \\
\text { our workforce } \\
\text { 7. Internal policies prevent discrimination in employees' } \\
\text { compensation and promotion } \\
\text { Economic CSR } \\
\text { 1.This organisation has been successful at maximising profits } \\
\text { 2.This organisation tries to lower its operating costs } \\
\text { 3. This organisation's top management sets long term strategies }\end{array}$ \\
\hline $\begin{array}{l}\text { Gwinner \& } \\
\text { Swanson (2003) } \\
\text { and Fisher \& } \\
\text { Wakefield (1998) }\end{array}$ & $\begin{array}{l}\text { Domain } \\
\text { Involvement }\end{array}$ & $\begin{array}{l}\text { Philanthropic initiatives } \\
\text { 1. Supporting weaker social teams is very important to me } \\
\text { 2. I think about supporting weaker social teams all the time } \\
\text { 3. I support weaker social teams whenever I can } \\
\text { Donations for children } \\
\text { 1. Unimportant - Important } \\
\text { 2. Of no concern - of concern to me } \\
\text { 3. Irrelevant - relevant } \\
\text { 4. Means nothing to me - means a lot to me } \\
\text { 5. Doesn't matter - matters to me }\end{array}$ \\
\hline Huang (2001) & $\begin{array}{l}\text { Relationship } \\
\text { management }\end{array}$ & $\begin{array}{l}\text { Trust } \\
\text { 1. Members of the organisation are truthful with us. } \\
\text { 2. Generally speaking, I do not trust the organisation. (R) } \\
\text { 3. The organisation keeps its promises. } \\
\text { Control Mutuality } \\
\text { 1. Generally speaking, the organisation and we (employees) are both } \\
\text { satisfied with the decision-making process. } \\
\text { 2. In most cases, during decision making, both the organisation and } \\
\text { we (employees) have equal influence. } \\
\text { Relationship Satisfaction } \\
\text { 1. Generally speaking, our relationship with the organisation has } \\
\text { problems. (R) } \\
\text { 2. In general, we are satisfied with the relationship with the } \\
\text { organisation. } \\
\text { 3. Our relationship with the organisation is good. } \\
\text { Relationship Commitment } \\
\text { 1. I do not wish to continue a relationship with the organisation. (R) } \\
\text { 2. I believe that it is worthwhile to try to maintain the relationship } \\
\text { with the organisation. } \\
\text { 3. I wish to keep a long-lasting relationship with the organisation. }\end{array}$ \\
\hline
\end{tabular}

This article is (C) Emerald Group Publishing and permission has been granted for this version to appear here (please insert the web address here). Emerald does not grant permission for this article to be further copied/distributed or hosted elsewhere without the express permission from Emerald Group Publishing Limited. 


\begin{tabular}{|c|c|c|}
\hline $\begin{array}{lr}\text { Goyete, } & \text { Ricard, } \\
\text { Bergeron } & \text { and } \\
\text { Marticotte } & (2010)\end{array}$ & Word of Mouth & $\begin{array}{l}\text { Positive WOM } \\
\text { 1.I recommended this company } \\
\text { 2. I speak of this company's good sides. } \\
\text { 3. I am proud to say to others that I am this company's employee. } \\
\text { 4. I strongly recommend people buy products from this company. } \\
\text { 5. I mostly say positive things to others. } \\
\text { 6. I have spoken favourably of this company to others. }\end{array}$ \\
\hline Hurtt (2010) & Scepticism & $\begin{array}{l}\text { Search for Knowledge } \\
\text { 1. I like searching for knowledge } \\
\text { 2. I relish learning } \\
\text { 3. The prospect of learning excites me } \\
\text { 4. Discovering new information is fun } \\
\text { 5. I think that learning is exciting } \\
\text { 6. I enjoy trying to determine if what I read or hear is true } \\
\text { Self Confidence } \\
\text { 1. I feel good about myself } \\
\text { 2. I have confidence in myself } \\
\text { 3. I am self-assured } \\
\text { 4. I am confident of my abilities } \\
\text { Interpersonal Understanding } \\
\text { 1. The actions people take and the reasons for those actions are } \\
\text { fascinating } \\
\text { 2. I like to understand the reason of other people's behaviour } \\
\text { 3. I am interested in what causes people to behave the way they do } \\
\text { Self-determining } \\
\text { 1. I often accept other people's explanations without further thought } \\
\text { 2. It is easy for other people to convince me } \\
\text { 3. I tend to immediately accept what others tell me } \\
\text { Suspension of Judgement } \\
\text { 1. I like to ensure that I've considered most available information } \\
\text { before making a decision } \\
\text { 2. I take my time when making decisions } \\
\text { 3. I dislike having to make decision quickly } \\
\text { 4. I wait to decide on issues until I can get more information } \\
\text { 5. I don't like to decide until I have looked at all the readily available } \\
\text { information } \\
\text { Questioning mind } \\
\text { 1. I frequently question things that I see or hear } \\
\text { 2. My friends tell me that I often question things that I see or hear } \\
\text { 3. I often reject statements unless I have proof they are true }\end{array}$ \\
\hline
\end{tabular}

This article is (C) Emerald Group Publishing and permission has been granted for this version to appear here (please insert the web address here). Emerald does not grant permission for this article to be further copied/distributed or hosted elsewhere without the express permission from Emerald Group Publishing Limited. 
Table 2: Regression Model for Word of Mouth

\begin{tabular}{|c|c|c|c|c|c|c|}
\hline \multicolumn{7}{|l|}{ Model } \\
\hline & \multirow[t]{2}{*}{ Beta } & \multirow[t]{2}{*}{ SE } & \multirow[t]{2}{*}{$t$} & \multirow[t]{2}{*}{ Sig. } & \multicolumn{2}{|c|}{ Collinearity Statistics } \\
\hline & & & & & Tolerance & VIF \\
\hline Involvement children donations & .098 & .019 & 5.304 & .000 & .569 & 1.758 \\
\hline Involvement_philantropies & .065 & .018 & 3.591 & .000 & .592 & 1.689 \\
\hline Control_Mutuality & .179 & .019 & 9.326 & .000 & .534 & 1.873 \\
\hline Relationship_Commitment & .243 & .019 & 12.795 & .000 & .542 & 1.845 \\
\hline Relationship_Satisfaction & .228 & .020 & 11.638 & .000 & .509 & 1.964 \\
\hline Trust & .249 & .020 & 12.700 & .000 & .507 & 1.971 \\
\hline Self_Determining & .014 & .020 & .683 & .495 & .487 & 2.055 \\
\hline Search for Knowledge & .031 & .020 & 1.517 & .130 & .468 & 2.137 \\
\hline Questioning mind & .044 & .020 & 2.246 & .025 & .508 & 1.969 \\
\hline Self Confidence & .035 & .021 & 1.662 & .097 & .437 & 2.289 \\
\hline Suspension_of Judgement & .040 & .020 & 2.015 & .044 & .495 & 2.022 \\
\hline Interpersonal_Understanding & .033 & .021 & 1.573 & .116 & .437 & 2.290 \\
\hline $\mathrm{F}$ & \multicolumn{6}{|c|}{376.028} \\
\hline$R^{2}$ & \multicolumn{6}{|c|}{.783} \\
\hline$R_{a d j}^{2}$ & \multicolumn{6}{|c|}{.780} \\
\hline$d f$ & \multicolumn{6}{|c|}{12} \\
\hline
\end{tabular}

This article is (C) Emerald Group Publishing and permission has been granted for this version to appear here (please insert the web address here). Emerald does not grant permission for this article to be further copied/distributed or hosted elsewhere without the express permission from Emerald Group Publishing Limited. 
Table 3: Regression Model for Control Mutuality

\begin{tabular}{|c|c|c|c|c|c|c|}
\hline \multicolumn{7}{|l|}{ Model } \\
\hline & \multirow[t]{2}{*}{ Beta } & \multirow[t]{2}{*}{ SE } & \multirow[t]{2}{*}{$t$} & \multirow[t]{2}{*}{ Sig. } & \multicolumn{2}{|c|}{ Collinearity Statistics } \\
\hline & & & & & Tolerance & VIF \\
\hline Discrationary_CSR & .157 & .039 & 4.041 & .000 & .425 & 2.351 \\
\hline Economic_CSR & .171 & .040 & 4.234 & .000 & .390 & 2.561 \\
\hline Ethical_legal_CSR & .218 & .041 & 5.321 & .000 & .379 & 2.641 \\
\hline Involvement_children_donations & .165 & .031 & 5.241 & .000 & .645 & 1.551 \\
\hline Involvement_philantropies & .134 & .032 & 4.237 & .000 & .635 & 1.575 \\
\hline Self_Determining & .014 & .036 & .380 & .704 & .499 & 2.004 \\
\hline Search_for_Knowledge & .089 & .036 & 2.435 & .015 & .481 & 2.079 \\
\hline Questioning_mind & .104 & .035 & 2.958 & .003 & .516 & 1.940 \\
\hline Self_Confidence & .029 & .038 & .778 & .437 & .444 & 2.252 \\
\hline Suspension_of_Judgement & .056 & .035 & 1.584 & .114 & .510 & 1.960 \\
\hline Interpersonal_Ūnderstanding & .068 & .038 & 1.797 & .073 & .441 & 2.266 \\
\hline $\mathrm{F}$ & \multicolumn{6}{|c|}{87.964} \\
\hline$R^{2}$ & \multicolumn{6}{|c|}{.617} \\
\hline$R_{\text {adj. }}^{2}$ & \multicolumn{6}{|c|}{.610} \\
\hline$d f$ & \multicolumn{6}{|c|}{11} \\
\hline
\end{tabular}

This article is (C) Emerald Group Publishing and permission has been granted for this version to appear here (please insert the web address here). Emerald does not grant permission for this article to be further copied/distributed or hosted elsewhere without the express permission from Emerald Group Publishing Limited. 
Table 4: Regression Model for Relationship Commitment

\begin{tabular}{|c|c|c|c|c|c|c|}
\hline \multicolumn{7}{|l|}{ Model } \\
\hline & \multirow[t]{2}{*}{ Beta } & \multirow[t]{2}{*}{ SE } & \multirow[t]{2}{*}{$t$} & \multirow[t]{2}{*}{ Sig. } & \multicolumn{2}{|c|}{ Collinearity Statistics } \\
\hline & & & & & Tolerance & VIF \\
\hline Discrationary_CSR & .144 & .039 & 3.698 & .000 & .425 & 2.351 \\
\hline Economic_CSR & .211 & .041 & 5.199 & .000 & .390 & 2.561 \\
\hline Ethical_legal_CSR & .189 & .041 & 4.576 & .000 & .379 & 2.641 \\
\hline Involvement_children_donations & .195 & .032 & 6.168 & .000 & .645 & 1.551 \\
\hline Involvement_philantropies & .134 & .032 & 4.217 & .000 & .635 & 1.575 \\
\hline Self_Determining & -.002 & .036 & -.062 & .950 & .499 & 2.004 \\
\hline Search_for_Knowledge & .050 & .037 & 1.377 & .169 & .481 & 2.079 \\
\hline Questioning_mind & .090 & .035 & 2.553 & .011 & .516 & 1.940 \\
\hline Self_Confidence & .098 & .038 & 2.571 & .010 & .444 & 2.252 \\
\hline Suspension_of_Judgement & -.033 & .036 & -.919 & .359 & .510 & 1.960 \\
\hline Interpersonal_Understanding & .111 & .038 & 2.916 & .004 & .441 & 2.266 \\
\hline $\mathrm{F}$ & \multicolumn{6}{|c|}{86.566} \\
\hline$R^{2}$ & \multicolumn{6}{|c|}{.613} \\
\hline$R_{\text {adj. }}^{2}$ & \multicolumn{6}{|c|}{.606} \\
\hline$d f$ & \multicolumn{6}{|c|}{11} \\
\hline
\end{tabular}

This article is (C) Emerald Group Publishing and permission has been granted for this version to appear here (please insert the web address here). Emerald does not grant permission for this article to be further copied/distributed or hosted elsewhere without the express permission from Emerald Group Publishing Limited. 
Table 5: Regression Model for Relationship Satisfaction

\begin{tabular}{|c|c|c|c|c|c|c|}
\hline \multicolumn{7}{|l|}{ Model } \\
\hline & \multirow[t]{2}{*}{ Beta } & \multirow[t]{2}{*}{ SE } & \multirow[t]{2}{*}{$t$} & \multirow[t]{2}{*}{ Sig. } & \multicolumn{2}{|c|}{ Collinearity Statistics } \\
\hline & & & & & Tolerance & VIF \\
\hline Discrationary_CSR & .140 & .039 & 3.627 & .000 & .425 & 2.351 \\
\hline Economic_CSR & .073 & .040 & 1.804 & .072 & .390 & 2.561 \\
\hline Ethical_legal_CSR & .260 & .041 & 6.331 & .000 & .379 & 2.641 \\
\hline Involvement_children_donations & .145 & .031 & 4.602 & .000 & .645 & 1.551 \\
\hline Involvement_philantrōpies & .124 & .032 & 3.920 & .000 & .635 & 1.575 \\
\hline Self_Determining & .116 & .036 & 3.250 & .001 & .499 & 2.004 \\
\hline Search_for_Knowledge & .072 & .036 & 1.986 & .048 & .481 & 2.079 \\
\hline Questioning_mind & .025 & .035 & .719 & .472 & .516 & 1.940 \\
\hline Self_Confidence & .074 & .038 & 1.946 & .052 & .444 & 2.252 \\
\hline Suspension_of_Judgement & .147 & .035 & 4.158 & .000 & .510 & 1.960 \\
\hline Interpersonal_Understanding & .037 & .038 & .979 & .328 & .441 & 2.266 \\
\hline $\mathrm{F}$ & \multicolumn{6}{|c|}{88.165} \\
\hline$R^{2}$ & \multicolumn{6}{|c|}{.618} \\
\hline$R_{\text {adj. }}^{2}$ & \multicolumn{6}{|c|}{.611} \\
\hline$d f$ & \multicolumn{6}{|c|}{11} \\
\hline
\end{tabular}

This article is (C) Emerald Group Publishing and permission has been granted for this version to appear here (please insert the web address here). Emerald does not grant permission for this article to be further copied/distributed or hosted elsewhere without the express permission from Emerald Group Publishing Limited. 
Table 6: Regression Model for Trust

\begin{tabular}{|c|c|c|c|c|c|c|}
\hline \multicolumn{7}{|l|}{ Model } \\
\hline & \multirow[t]{2}{*}{ Beta } & \multirow[t]{2}{*}{ SE } & \multirow[t]{2}{*}{$t$} & \multirow[t]{2}{*}{ Sig. } & \multicolumn{2}{|c|}{ Collinearity Statistics } \\
\hline & & & & & Tolerance & VIF \\
\hline Discrationary_CSR & .158 & .039 & 3.627 & .000 & .425 & 2.351 \\
\hline Economic_CSR & .173 & .041 & 1.804 & .000 & .390 & 2.561 \\
\hline Ethical_legal_CSR & .153 & .041 & 6.331 & .000 & .379 & 2.641 \\
\hline Involvement_children_donations & .178 & .032 & 4.602 & .000 & .645 & 1.551 \\
\hline Involvement_philantropies & .117 & .032 & 3.920 & .000 & .635 & 1.575 \\
\hline Self_Determining & .139 & .036 & 3.250 & .000 & .499 & 2.004 \\
\hline Search_for_Knowledge & .114 & .037 & 1.986 & .002 & .481 & 2.079 \\
\hline Questioning_mind & .065 & .035 & .719 & .067 & .516 & 1.940 \\
\hline Self_Confidence & .038 & .038 & 1.946 & .312 & .444 & 2.252 \\
\hline Suspension_of_Judgement & .090 & .035 & 4.158 & .012 & .510 & 1.960 \\
\hline Interpersonal_Understanding & -.009 & .038 & .979 & .818 & .441 & 2.266 \\
\hline $\mathrm{F}$ & \multicolumn{6}{|c|}{87.165} \\
\hline$R^{2}$ & \multicolumn{6}{|c|}{.615} \\
\hline$R_{a d j}^{2}$ & \multicolumn{6}{|c|}{.608} \\
\hline$d f$ & \multicolumn{6}{|c|}{11} \\
\hline
\end{tabular}

This article is (C) Emerald Group Publishing and permission has been granted for this version to appear here (please insert the web address here). Emerald does not grant permission for this article to be further copied/distributed or hosted elsewhere without the express permission from Emerald Group Publishing Limited. 


\section{Appendix A1 Factors and Reliability test}

Factor loadings Cronbach's

Alpha

$\mathrm{a}=.875$

Discretionary CSR

1.This organisation gives adequate contribution to charities

2. This organisation encourages partnership with local businesses and schools

Ethical-legal CSR

1.Flexible company policies enable employees to better co-ordinate work and personal life

2. Fairness towards co-workers and business partners is an integral part of our employee

.896

evaluation process

3. A confidential procedure is in place for employees to report any misconduct at work

4. Our salespersons and employees are required to provide full and accurate information to all

5. This company seeks to comply with all laws regulating hiring and employee benefits

6. This organisation has programmes that encourage the diversity of our workforce

7. Internal policies prevent discrimination in employees' compensation and promotion

\section{Economic CSR}

1.This organisation has been successful at maximising profits

2.This organisation tries to lower its operating costs

3. This organisation's top management sets long term strategies

\section{Philanthropic initiatives}

1. Supporting weaker social teams is very important to me

2. I think about supporting weaker social teams all the time $\quad .919$

3. I support weaker social teams whenever I can $\quad .920$

Donations for children

1. Unimportant - Important

2. Of no concern - of concern to me $\quad .896$

3. Irrelevant - relevant $\quad .900$

4. Means nothing to me - means a lot to me $\quad .888$

5. Doesn't matter - matters to me $\quad .913$

Trust

1. Members of the organisation are truthful with us.

2. Generally speaking, I do not trust the organisation. (R)

Control Mutuality

1. Generally speaking, the organisation and we (employees) are both satisfied with the

decision-making process.

2. In most cases, during decision making, both the organisation and we (employees) have equal

influence.

\section{Relationship Satisfaction}

1. Generally speaking, our relationship with the organisation has problems. (R)

2. In general, we are satisfied with the relationship with the organisation. $\quad .944$

3. Our relationship with the organisation is good.

Relationship Commitment

1. I do not wish to continue a relationship with the organisation. (R)

2 . I believe that it is worthwhile to try to maintain the relationship with the organisation

3. I wish to keep a long-lasting relationship with the organisation.

1.I recommended this company

2. I speak of this company's good sides.

3. I am proud to say to others that I am this company's employee.

4. I strongly recommend people buy products from this company.

6. I have spoken favourably of this company to others.

\section{Search for Knowledge}

1. I like searching for knowledge

3. The prospect of learning excites me $\quad .889$

4. Discovering new information is fun $\quad .902$

5. I think that learning is exciting $\mathrm{a}=.929$

$a=.922$

$a=.904$

$a=.940$

$\mathrm{a}=.909$

$$
\mathrm{a}=.931
$$

$a=.934$

$\mathrm{a}=.959$

$\mathrm{a}=.950$

This article is (C) Emerald Group Publishing and permission has been granted for this version to appear here (please insert the web address here). Emerald does not grant permission for this article to be further copied/distributed or hosted elsewhere without the express permission from Emerald Group Publishing Limited. 
1. I feel good about myself

2. I have confidence in myself $\quad .904$

3. I am self-assured $\quad .911$

$\begin{array}{ll}\text { 4. I am confident of my abilities } & .901\end{array}$

Interpersonal Understanding

1. The actions people take and the reasons for those actions are fascinating $\quad .912$

2. I like to understand the reason of other people's behaviour $\quad .907$

3. I am interested in what causes people to behave the way they do 904

\section{Self-determining}

1. I often accept other people's explanations without further thought $\quad .909$

2. It is easy for other people to convince me $\quad .903$

3. I tend to immediately accept what others tell me 912

Suspension of Judgment

1. I like to ensure that I've considered most available information before making a decision $\quad .895$

2. I take my time when making decisions $\quad .892$

3. I dislike having to make decision quickly $\quad .892$

4. I wait to decide on issues until I can get more information $\quad .890$

5. I don't like to decide until I have looked at all the readily available information 881

Questioning mind

1. I frequently question things that I see or hear $\quad .910$

2. My friends tell me that I often question things that I see or hear $\quad .913$

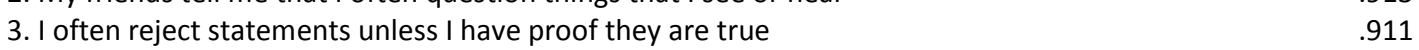

This article is (C) Emerald Group Publishing and permission has been granted for this version to appear here (please insert the web address here). Emerald does not grant permission for this article to be further copied/distributed or hosted elsewhere without the express permission from Emerald Group Publishing Limited. 